\title{
Value Congruence and Organizational Commitment: Does Work Happiness Matter?
}

\author{
Oyekunle Oyelakin*, Adekunle D. Shodeinde \& Idi Jamok Arandong \\ Department of Business Administration, Faculty of Management Science, University of Jos, Nigeria \\ *Corresponding author: oyekunleoyelakin@yahoo.com
}

Citation: Oyelakin, O., Shodeinde, A. D. \& Arandong, I. J. (2021). Value Congruence and Organizational Commitment: Does Work Happiness Matter? Business Perspective Review 3(2), 14-26. DOI: https://doi.org/10.38157/businessperspective-review.v3i2.348

\section{Research Article}

\begin{abstract}
Purpose: Lack of employee commitment to their organization has been reported as one of the numerous challenges faced by the Nigerian Civil Service. The study investigated the mediating role of work happiness on the relationship between value congruence and organizational commitment in Federal Public Service in Abuja, Nigeria.

Method: Data were collected from the Nigerian Civil Service staff in Abuja, Nigeria. Following the random sampling technique, a total of 386 responses were used for data analysis. Data were analyzed using SmartPLS 3.

Results: Findings revealed that value congruence and work happiness have a positive and significant effect on organizational commitment. Work happiness is also found to have fully mediated the relationship between value congruence and organizational commitment.

Implication: The study implies that value congruence and work happiness are factors to be considered in getting employees committed to organizational goals and objectives. It also recommends that regulatory authority should ensure a congenial environment for the staff of Federal Civil Service that would make them happy and committed to the organization.
\end{abstract}

Keywords: Value congruence, Work happiness, Organizational commitment, Civil Service, Nigeria

\section{Introduction}

The most valuable resource that determines the success or failure of an organization is its employees (Ahmed \& Top, 2021; Gündüz, 2014). An organization cannot function efficiently and achieve its stated goals and objectives without a committed workforce (Aziz et al., 2021; Mohammed et al., 2020; Gulbahar, et al, 2014). Globally, most especially in developing countries, it has been argued that public employees work three hours less per week and almost one month less per year than employees in the private sectors (Johnson, 2020; Richwine, 2012). These substantial work differences have persisted over time and have been criticized as bad public sectors employment practices which are caused by shorter workdays, excess work leave, vacations and have thus affected their level of commitment to their respective job and therefore should be a major concern to the government.

In Nigeria the case was not the same, lack of employee commitment to their organization has been reported to be one of the numerous challenges facing Nigeria Civil Service according to immediate past Head of Service, Oyo-Ita (2018). This, among many others, has made Nigeria Civil Service less competitive. The lack of ability of the civil service has affected developmental efforts and government policies. Despite the effort of consecutive administration in Nigeria to make changes with the sole aim of 
enhancing the capability and productivity in civil service, the service is still underperforming (Salisu, 2001).

Value congruence in life and the workplace is associated with higher work happiness and lower burnout (Dunaetz, et al, 2020; Veage, et al., 2014) i.e. when an employee's value is similar to that of the organization, an employee enjoys work happiness. As argued by (Merida-Lopez et al., 2018: Erdogan, et. al., 2012) happiness in the workplace can influence satisfaction derived from work, development in a chosen career, style of leadership, job condition, and most especially value congruence or personorganization fit. Bissett (2014) emphasizes that value can be congruence if there is consistency and agreement between personal values and organizational values and also the extent to which employee compromise their value to meet organizational expectations. A match between individual values and organizational values will result in a positive outcome for the organization. Bao, et al., (2012), argued that positive outcomes may include; job satisfaction, reduce employee turnover, employee commitment, increase in productivity, etc. Shared values between employee and organization can help in creating a committed workforce to scale through the dynamic and competitive nature of business globally (Auster \& Freeman, 2013).

An employee who is happy with a particular job will perform assigned jobs efficiently and effectively and therefore be committed to the job and subsequently to the organization (Agustiena, et. al., 2020; Gangai \& Agrawal, 2015). This will allow the organization the opportunity to survive and remain highly competitive in the global business world (Radosavljević, Vesna \& Dragić 2017). Employees may exhibit good/bad or positive/negative attitudes depending on so many factors found in the workplace (NdubuisiOkolo, et al., 2017), and sometimes outside the workplace, this attitude could affect their extent of commitment to the goals and objectives of the organization. Factors within a workplace can be attributed to the working environment, style of leadership, pay while factors outside the workplace can be family background, economic factors, etc.

Examining employee happiness is of great importance and demand to be looked at by Human Resource professionals (Alnuaimi 2018). Keeping employees happy will enable them to perform a task for a longer period efficiently, thus the happiness or well-being of an employee both physically and mentally is very important to the success of an organization (Bataineh, 2019) which can be achieved through employee commitment to organizational goals and objectives. Ferssizidis, et al., 2010) posited that employees who have succeeded in keeping their profession over time were as a result of happiness derived from work. So, therefore, when an employee is happy, the feelings, emotions, time, and energy invested toward an individual, group of people and task will increase (Mateu, 2015) and therefore will have a direct impact on organizational commitment.

Extant literature reviews have documented a positive and significant effect between value congruence and performance, productivity, and organizational success in the workplace (e.g. Khaled 2019; Wesarat, et al., 2015; Veage, et al., 2014). However, studies concerning value congruence and organizational commitment are scarce. Therefore, studies (e.g. Joo \& Lee 2017; Moreno \& Ibarra, 2017; Leuty \& Hansen, 2012), states that despite the importance of happiness in the life of an individual and workplace little scientific research has focused on the matter in the field of management and therefore recommends the need for more research to be conducted.

The study of Gavin and Mason (2004) found that employee happiness at work helps to cause and bring about organizational success as a result of employee commitment. Studies such as (Fisher, 2010; Gavin \& Mason, 2004) in their studies found that employee happiness can lead to various organizational outcomes. Despite studies conducted, there are few studies concerning work happiness and organizational commitment (Agustiena, et. al., 2020; Khaled, 2019; Bataineh, 2019). Although there has been an increasing interest in public sector organizations, most previous research on organizational commitment is

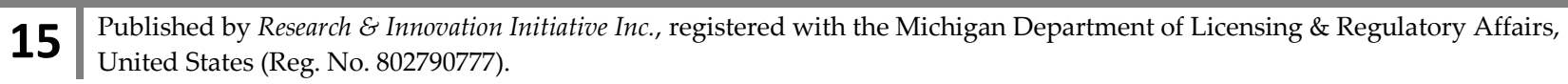


based on studies of private-sector ones (Hansen \& Kjeldsen, 2017). These discrepancies brought about the need to empirically examine the effect of work happiness and organizational commitment in Nigerian civil service.

\section{Literature Review and Hypotheses Development}

This study is grounded on organization support theory. According to Eisenberger, e al., (1986), the concerns by managers on the needs of their employees will go a long way to enhance their commitment. Part of the need that can enhance commitment is for an employee to share similar values (value congruence) with the organization and be happy in discharging their duties. Therefore, this study is designed to see the influence of value congruence on organizational commitment while work happiness is considered as a mediating variable.

\subsection{Organizational Commitment}

According to Porters, et al., (1974) organizational commitment is the ability of an employee to attempt and strive to achieve excellence on organizational matters to maintain membership in the organization. Organizational commitment could be outlined in three dimensions; a) the determination to stay as an employee of an organization b) the capability to attach a reasonable effort to complete task c) the belief and alignment with organizational values, goals, and objectives (Becker et al. 1995; Batemen \& Strasser 1984; Mowday et. al. 1982). Northcraft and Neale (1996) suggested that commitment can be influenced by personal and organizational factors. Personal factors include; employee age, years spent disposition internal and external control attribution). Organizational factors include; type of leadership, job design, working environment, etc.

\subsection{Value Congruence}

According to Bhargava and Pradhan (2016), value congruence is seen as the extent to which two entities have similar or the same values. These values can exist between employees and co-workers, employees and supervisors, and finally employees and organization. Literature has documented value congruence as the main operationalization of person-organization Fit (Liedtka, 1989; Chatman, 1991; Hoffman, Bynum, Piccolo, \& Sutton, 2011) and shown to have a strong relationship with work attitude and behavior. This study defines value congruence as an alignment of employees' values and organizational values to achieve organizational success.

\subsection{Work Happiness}

Mateu (2015) sees happiness as a subjective phenomenon and could not be measured outrightly and it depends on how an individual reports it to others through interpretation, expectation, and circumstances in the given environment. Wesarat et al., (2015) see happiness at the workplace as the extent to which an employee is contented with his work and life in general. Susniene and Jurkauskas (2009), define happiness as a personal evaluation, which is measured by the individual quality of life with the subjective perception of happiness. In this study, work happiness is an emotional state which is attributed to feelings of joy, satisfaction, contentment, and fulfillment.

\subsection{Value Congruence and Organizational Commitment}

Dunaetz, et. al, (2020) examines the relationship between value congruence (between church attenders and their churches) and organizational commitment. From the sample of 252 church attendants, the study found that the value congruence of church attendant affective is positively correlated with church commitment. Also, Tabane, et al., (2013) examined whether organizational value and personal value

\footnotetext{
16 Published by Research \& Innovation Initiative Inc., registered with the Michigan Department of Licensing \& Regulatory Affairs,
} United States (Reg. No. 802790777). 
congruence affect organizational commitment. The study found a significant positive relationship between personal values and organizational commitment.

The study of Stephanie et. al. (2014) explored how does value congruence and well-being lead to burnout among health workers. The study found that value congruence affects the well-being of health workers. This is to say that employee whose value is consistent with that of the health organization has lower burnout. Sortheix (2014) investigated how personal values influence wellbeing with an emphasis on contexts in which the relationship exists. The study found that the effect between value and wellbeing can exist based on the social context that individuals inhabit the organization to which an individual belongs and the developmental situation of the environment.

The above studies were conducted in a different domain other than the one adopted in this. Also, the construct in the study differs from the one employed in this current study. Also, few empirical studies were found in the works of literature, this justifies the need for more studies to be conducted in the field. Therefore the study hypothesizes that:

\section{$\boldsymbol{H}_{1}$ : Value congruence affects the organizational commitment of the employees.}

\subsection{Work Happiness and Organizational Commitment}

Agustiena, et. al. (2020) examined the role of happiness at work in improving employee performance. Analysis of data collected from 200 respondents, shows that happiness at work has no direct effect on employee performance, but when the relationship was mediated by work motivation there was a positive effect between happiness at work on employee performance. The study of Khaled, (2019) examined the relationship between happiness and employee performance among 289 employees in pharmaceutical industries in Jordan. The study found happiness to have a positive and significant effect on employee performance. Bataineh, (2019) stated happiness at work affects employee performance and concluded that happiness is a tool that can maximize the improvement of personal quality and employee performance.

Wesarat, et al., (2015) developed a conceptual model of happiness at the workplace and emphasized that employee happiness in an organization important indices of productivity and performance in any workplace. They further argued that happy employees will be are productive while those employees who are not happy may not be productive. Also, Fisher (2010) reviews the causes and consequences of happiness at the workplace to include work engagement, job satisfaction, and organizational commitment. Most studies have considered performance as a consequence of work happiness, however, this study posits that organizational commitment is a consequence of work happiness. Also, few empirical studies were found in the literature. This justifies the need for more studies to be conducted in the relation to work happiness and organizational commitment. Therefore the study hypothesizes that:

\section{$\boldsymbol{H}_{2}$ : Work Happiness affects the organizational commitment of the employees.}

\subsection{Work happiness as a Mediator}

Having found consistency in the relationship between value congruence and organizational commitment (Dunaetz, et. al, 2020; Tabane, et al., 2013) it is necessary to inquire into the relationship and find if work happiness mediates the relationship. Having previously recorded by literature that work happiness also affects organizational commitment (Fisher, 2010), this study however argued that the work happiness in mediating the relationship between value congruence is important in achieving organizational commitment in Federal Public Service in Abuja. Therefore the study hypothesizes that: 
H3: Work Happiness mediates the relationship between value congruence and organizational commitment.

\section{Research Framework}

Based on the literature above, the present study envisions the following research framework considering the relationship among Value congruence, work happiness, and organizational commitment.

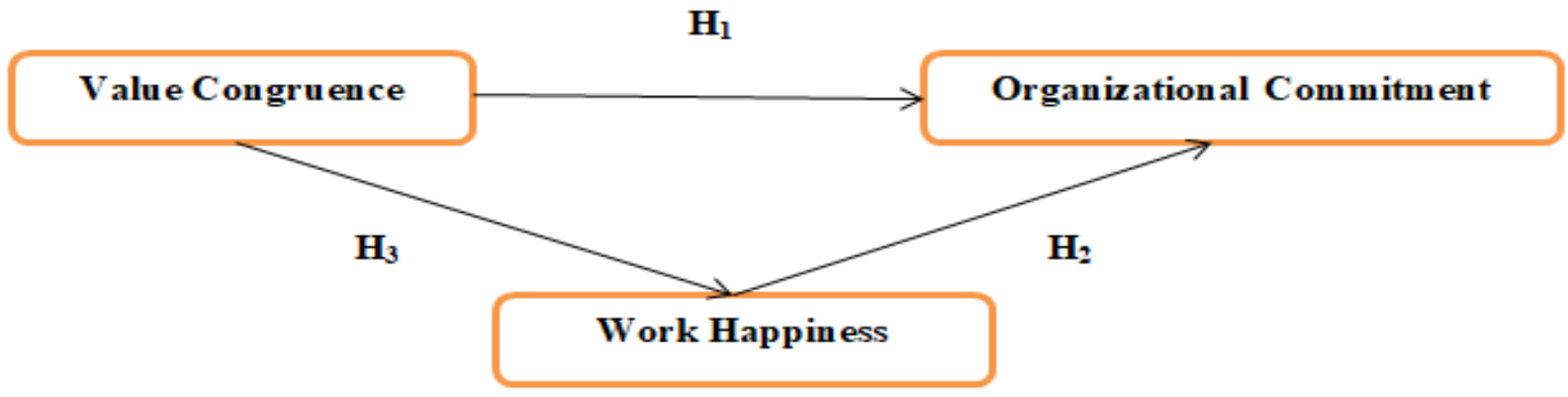

Fig.1: Research Framework

\section{Research Methodology}

The study used an explanatory research design based on a cross-sectional survey approach. The population of this study comprises the staff of the Federal Public Service of Nigeria which was estimated to be approximately 870,000 (Association of Senior Civil Servants of Nigeria, 2019).

The sample size was determined using the formula suggested by Yamane (1967) which was calculated to be three hundred and ninety-nine (399). To provide for the shortfall that may arise during data collection, an additional $10 \%$ was added to the minimum sample size of the study as suggested by Isreal (2013). Thus the study distributed 439 copies of questionnaires among the staff of the Federal Civil Service Commission.

Items used in measuring each variable in this study were adapted from various sources to fit the aims of this work. Six items were used to measure organizational commitment adapted from the work of Allen and Meyer (1990). Four (4) items were used to measure work happiness adapted from the work of Lyubomirsky and Lepper's (1999) four-item Subjective Happiness Scale. The 3-item scale developed by Cable and DeRue (2002) was used to measure value congruence. The data were analyzed by SmartPLS, using Partial Least Square Structural Equation Modelling (PLS-SEM).

\section{Data Analysis}

Out of the 412 questionnaires distributed, 386 completed responses were received, amounting to a 94\% response rate. The study further checked for missing data. In line with the recommendation of Hair et al., (2014) a 10\% maximum threshold is acceptable. The overall missing data in the set was found to be 18 out of 6,562 , constituting only $0.27 \%$ which is below the threshold. Thus the study used mean substitution to replace the missing data according to Hair et al., (2014).

Table 1 presents the demographic distribution employed in the study. The gender dispersal of sampled respondents indicates that $56.5 \%$ of the sampled respondents were males, which shows that males were more sampled than females. Thus, it can be concluded that most of the sampled respondents of this study are between the ages of 28-37 and ages $28-47$, with $34.4 \%$ and $29.3 \%$ respectively, therefore most of the

18 Published by Research \& Innovation Initiative Inc., registered with the Michigan Department of Licensing \& Regulatory Affairs, United States (Reg. No. 802790777). 
respondents are between ages 28 to 40. The academic qualification distribution of sampled respondents shows that most of the staff $(76.2 \%)$ have HND/B.Sc. as the minimum qualification.

Table 1: Demographic Characteristics of Respondents $(\mathbf{n}=386)$

\begin{tabular}{|lccc|}
\hline Characteristics & Frequency & Percentage & Cumulative Percentage \\
\hline Gender & & & \\
\hline Male & 218 & 56.5 & 56.5 \\
\hline Female & 168 & 43.5 & 100.0 \\
\hline Age Distribution & Frequency & Percentage & Cumulative Percentage \\
\hline $18-27$ & 64 & 16.6 & 16.6 \\
\hline $28-37$ & 129 & 33.4 & 50.0 \\
\hline $38-47$ & 113 & 29.3 & 79.3 \\
\hline Above 47 & 80 & 20.7 & 100.0 \\
\hline Academic Qualification & Frequency & Percentage & Cumulative Percentage \\
\hline O'Level & 10 & 2.6 & 2.6 \\
\hline ND & 33 & 8.5 & 11.1 \\
\hline HND/B.Sc. & 294 & 76.2 & 87.3 \\
\hline Postgraduate & 49 & 12.7 & 100.0 \\
\hline
\end{tabular}

\subsection{Accessing Model Fit}

Table 2 shows the indicators loading on their intended factors. According to Hair et al. (2014), loadings should not be below 0.5, indicators that don't meet the required threshold should be deleted to increase the reliability of the data. Also, Garson, (2016) advised that composite reliability should be greater than 0.7 and average variance extraction should be greater than 0.5 . From the table, the composite reliability ranges from 0.855 to 0.947 and the AVE of the variables ranges from 0.747 to 0.817 . This implies that the overall reliability measurement of the instrument is acceptable in terms of reliability thus depicting its internal consistency.

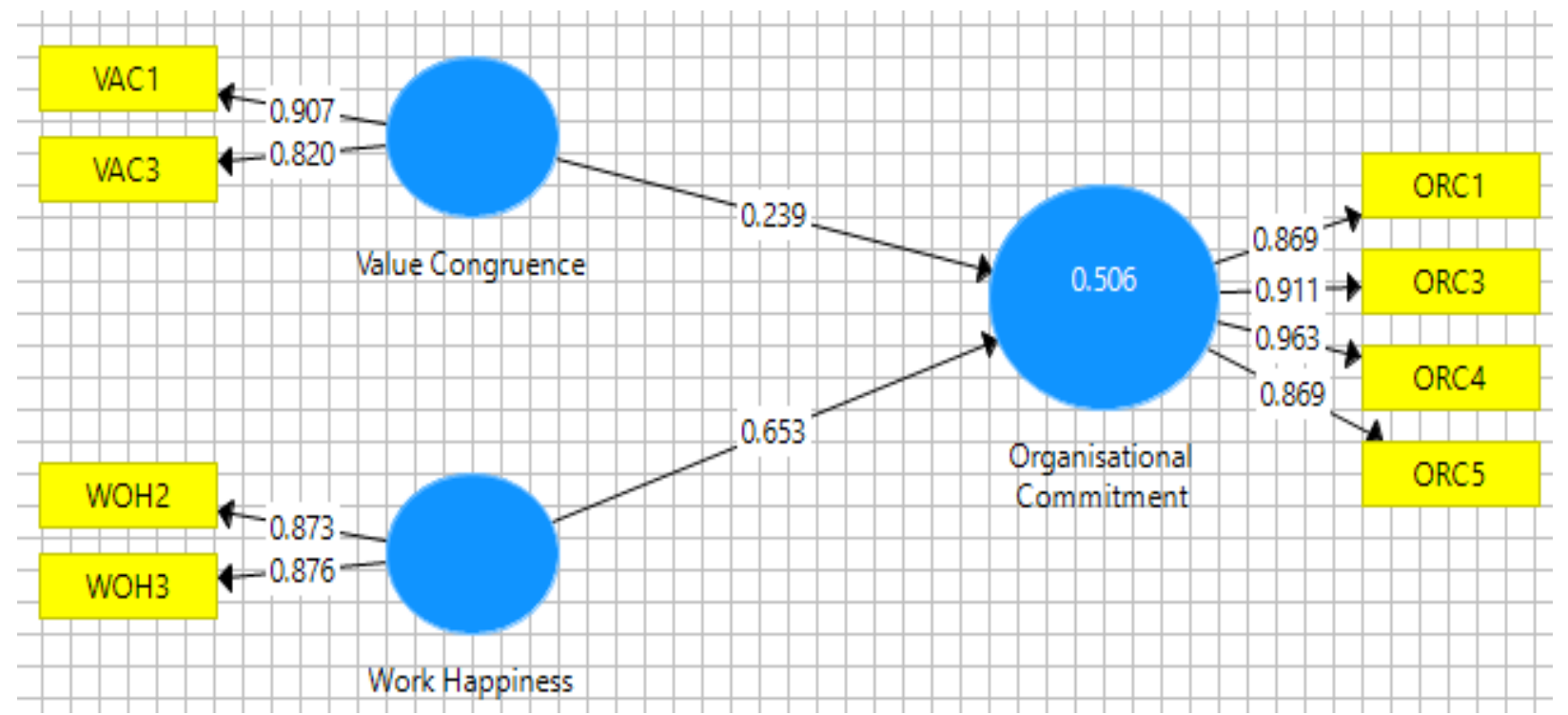

Fig. 2: Measurement Model 
Table 3 shows the result of discriminant validity, the bolded figures are the square root of each latent variable. It can be seen from the table that the AVE is higher than its correlation with other variables. Organizational Commitment has an AVE of 0.904, Value congruence has 0.864, and Work happiness 0.874. Concerning the discriminant validity criterion of Fornell-larcker the data shows discriminant validity (Garson, 2016).

Table 2: Construct Reliability and Validity

\begin{tabular}{|lcccc|}
\hline Construct & Items & Loadings & AVE & CR \\
\hline Value Congruence & WOH2 & 0.873 & 0.747 & 0.855 \\
\hline & WOH3 & 0.876 & & \\
\hline Work Happiness & VAC1 & 0.907 & 0.764 & 0.866 \\
\hline & VAC3 & 0.820 & & \\
\hline Organizational Commit. & ORC1 & 0.869 & 0.817 & 0.947 \\
\hline & ORC3 & 0.911 & & \\
\hline & ORC4 & 0.963 & & \\
& ORC5 & 0.869 & & \\
\hline
\end{tabular}

Note: AVE represents Average Variance Extracted; CR represents Composite Reliability; CA represents Cronbach's Alpha

Table 3: Discriminant Validity

\begin{tabular}{|lccc|}
\hline Construct & OC & VC & WH \\
\hline Organizational Commitment & $\mathbf{0 . 9 0 4}$ & & \\
\hline Value Congruence & 0.287 & $\mathbf{0 . 8 6 4}$ & \\
\hline Work Happiness & 0.670 & 0.073 & $\mathbf{0 . 8 7 4}$ \\
\hline
\end{tabular}

\subsection{Test of Hypotheses}

To determine the effect of value congruence and work happiness on the organizational commitment it is necessary to conduct a bootstrapping analysis was carried out using 386 cases and 5000 samples. The relationship between value congruence and organizational commitment shows a T Stat of 3.6 and the relationship between work happiness and organizational commitment shows a T Stat of 8.1. Since these values are greater than 2 , it is said to have a significant relationship.

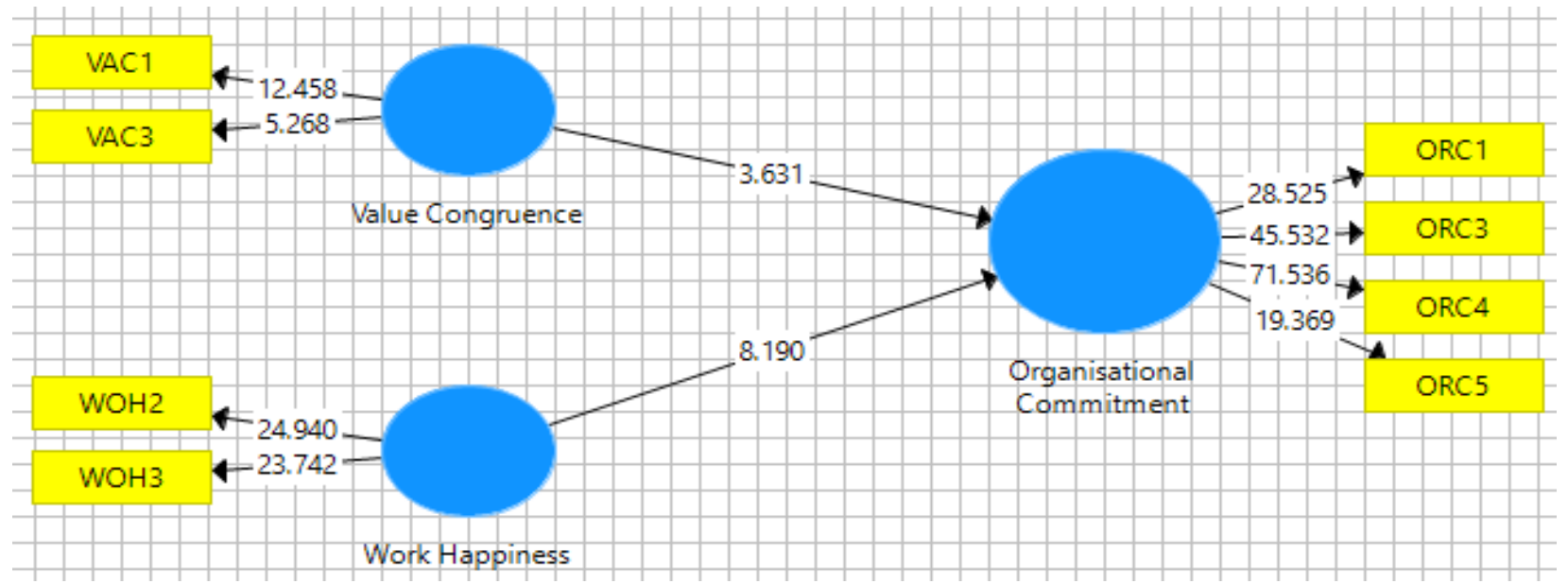

Fig. 3: Structural Model

Table 4, shows that value congruence has a positive and significant effect on organizational commitment, significant at $(\beta=0.23, p<0.01)$. Similarly, work happiness has a positive and significant effect on organizational commitment at $(\beta=0.65, p<0.01)$. Therefore the stated alternate hypotheses are accepted

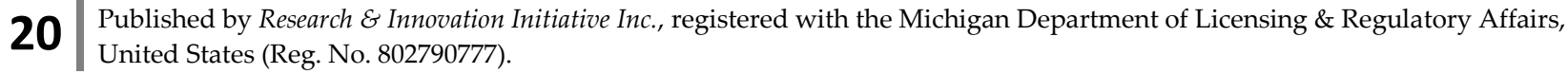


empirically. The $\mathrm{R}$ square of $50.6 \%$, indicates that value congruence and work happiness account for $50.6 \%$ of organizational commitment. $49.4 \%$ is accounted for by other variables that are not incorporated in the study.

Table 4: Path Coefficient

\begin{tabular}{|cccccc|}
\hline Hypotheses & Beta Value & Standard Deviation & P-Value & $\mathbf{R}^{\mathbf{2}}$ & Decision \\
\hline VAC $->$ OGC & 0.239 & 0.065 & $0.00^{* * *}$ & 0.506 & Supported \\
\hline WOH $->$ OGC & 0.653 & 0.082 & $0.00^{* * *}$ & & Supported \\
\hline
\end{tabular}

\subsection{Mediating Effect}

Before a mediating effect can be tested, three conditions must be met (Baron \& Kenny (1986). These conditions are; the independent variable must affect the dependent variable; the mediating variable must affect the dependent variable; when the mediating variable is included in the analysis, the effect of the independent variable on the dependent variable must disappear or diminish.

Since the result of our analysis met the first and second conditions, the study hereby proceeds to test for mediating effect of work happiness on the relationship between value congruence and organizational commitment. In figure 4 , the relationship between value congruence and organizational commitment shows a T Stat of 3.5 and the relationship between work happiness and organizational commitment shows a $\mathrm{T}$ Stat of 8.1, since these values are greater than 2, it is said to have a significant relationship. However, when testing for the mediating role of work happiness the relationship becomes insignificant with a T Stat value of 0.6 which is less than 2 .

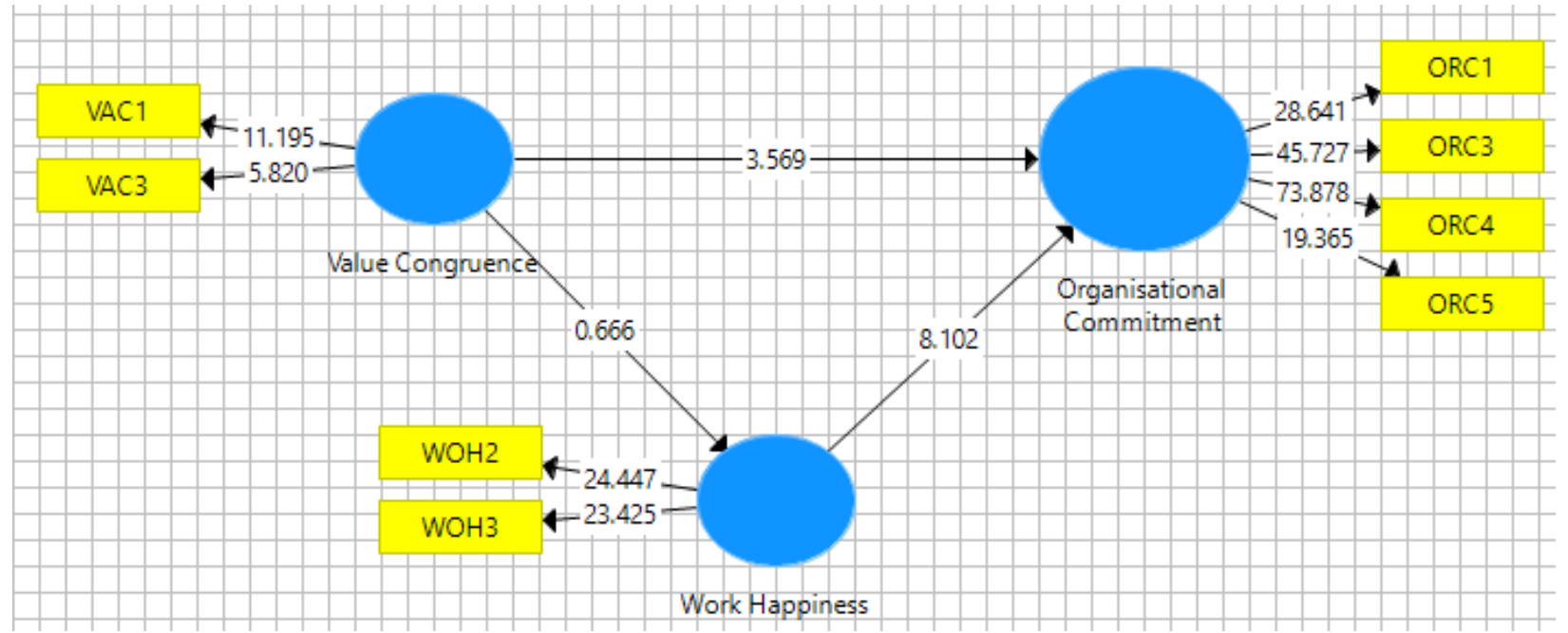

Fig. 4: Structural Model (Mediating Path)

Table 5: Mediated Path Coefficient

\begin{tabular}{|ccccc|}
\hline Hypotheses & $\begin{array}{c}\text { Beta } \\
\text { Value }\end{array}$ & $\begin{array}{c}\text { Standard } \\
\text { Deviation }\end{array}$ & P-Value & Decision \\
\hline VAC $->$ OGC & 0.238 & 0.066 & $0.00 * * *$ & Supported \\
\hline WOH $>$ C CS & 0.653 & 0.081 & $0.00 * * *$ & Supported \\
VAC $->$ WOH $->$ OGC & 0.074 & 0.111 & 0.54 & Supported \\
\hline
\end{tabular}

21 Published by Research \& Innovation Initiative Inc., registered with the Michigan Department of Licensing \& Regulatory Affairs, United States (Reg. No. 802790777). 
Table 6 shows the result of the hypotheses test. The study hypotheses are formulated in alternate forms; therefore all the hypotheses stated are supported empirically. From the table, it is seen that value congruence has a positive and significant effect on organizational commitment. So also is work happiness has a positive and significant effect on organizational commitment. Work happiness is seen to mediate the relationship between value congruence and organizational commitment. This was shown in the mediating path analysis when the relationship between value congruence and organizational commitment disappear, judging by the augment of Baron and Kenny (1986), the mediation is full

Table 6: Effect Size

\begin{tabular}{|lcc|}
\hline Construct & $\boldsymbol{f}^{2}$ & Effect size \\
\hline Value Congruence & 0.115 & Medium \\
\hline Work Happiness & 0.859 & Large \\
\hline
\end{tabular}

It is important to assess the effect size for the relationships between the independent variable on the dependent variable. From table 5, work happiness is said to have a large effect on organizational commitment. Thus the study concludes that work happiness is the most important variable that affects organizational commitment.

\section{Discussion of Findings}

Value congruence has a significant and positive effect on organizational commitment. This indicates that an increase in value congruence will lead to an increase in organizational commitment. It was discovered that when an employee's value is similar to that of the organization, he will have the motivation to stay for a long time with the organization and is likely to put forth the best of his efforts for the organization. The findings are supported by the theory of perceived organizational support on which this hypothesis was formulated. The theory posits that when employers' and employees' values align, the employees tend to be committed to organizational goals. This finding is empirically supported by the studies of Veage, et. al., (2014) and Bao, et. al., (2012) that found that value congruence was associated with a positive outcome including higher work happiness and commitment, among others.

Work happiness is found to have a significant effect on organizational commitment. This indicates that an increase in work happiness will lead to an increase in organizational commitment. Work happiness is found to have mediated the relationship between value congruence and organizational commitment ( $b$ $0.07 \mathrm{p}>0.01$ ). This is to say that having value aligned with the organization is not enough to determine commitment. The employees also need to be happy with their work. This finding is theoretically supported by the theory of perceived organizational support that argues that despite the relationship that exists between value congruence and organizational commitment work happiness is a valuable driver to organizational commitment. This finding is empirically supported by the findings of the study of Gangai \& Agrawal, (2015), and Radosavljević, et. al., (2017) who found that a happy employee is more committed to work and perform more effectively and efficiently.

\section{Conclusion and Implications}

The study examined the mediating role of work happiness on the relationship between value congruence and organizational commitment. It shows that both value congruence and work happiness have a positive and significant effect on organizational commitment. Also, work happiness was found to have fully mediated the relationship between value congruence and organizational commitment. The study, therefore, concludes that both work happiness and value congruence are important factors to be considered to make employees committed to organizational objectives and goals. Value congruence can be addressed during the hiring process by matching applicant value profile with that of the organization,

22 Published by Research \& Innovation Initiative Inc., registered with the Michigan Department of Licensing \& Regulatory Affairs, United States (Reg. No. 802790777). 
socializing new employees towards organizational culture and value, and putting strategies in place that directly impact trust and communication. This will make employees more committed to the organization. Also, when employees are paired with the right subordinate, respected, and given financial security, they tend to be happy and this goes a long way in exhibiting commitment on the part of the employee. Achieving greater success in the aforementioned variables will help employees in Federal Civil Service, Abuja stay committed to the organization. The study recommends that government who serves as the regulatory authority should provide staff of the Federal Civil Service with conditions that would made them happy to make them committed to organizational goals and objectives.

The study would be of immense benefit to the government, human resource management of federal ministries, Abuja, and academic researchers. It would help in designing and implementing strategies that will improve the performance of employees. The study would also be useful to the organized private sector as well as the general public in their search for ways of enhancing the commitment of employees.

\section{Direction for future research}

Future researchers should focus on a detailed comparative analysis between the public and private sectors. Other domains such as Agencies and other government departments should also be considered. More study is recommended using a different moderating and mediating variables.

Authors' Contributions: Adekunle D. Shodeinde and Idi, Jamok Arandong conceived the idea, developed appropriate methodology for the article and collected data. Oyekunle Oyelakin analyzed the data while Oyekunle Oyelakin wrote the paper.

Conflict of Interest: The authors declare no conflict of interest.

\section{REFERENCES}

Agustien, E., \& Drahen, P. (2020). How does Happiness at Work Affect Employee Performance in the Head Office of BKKBN? Hasanuddin Economics and Business Review, 4(2), 58-64.

Ahmed, J., \& Top, C. (2021). HRM Impact on Employee Commitment: Moderation of Employee. Journal of Global Economics and Business, 2(5), 117-130.

Allen, N. J. \& Meyer, J. P. (1990). The Measurement and Antecedents of Affective, Continuance, and Normative Commitment to the Organization. Journal of Occupational Psychology 63, 1-18.

Alnuaimi, A. A. (2018). Happiness at Work in the UAE: The Role of Leadership Style and Human Resource Management. A Thesis Submitted to The University of Manchester for the Degree of Doctor of Philosophy In the Faculty of Humanities.

Association of Senior Civil Servants of Nigeria (2019).

Auster, E. R., \& Freeman, R. E. (2013). Values and Poetic Organizations: Beyond Value Fit Toward Values Through Conversation. Journal of Business Ethics, 1-11.

Aziz, H. M., Othman, B. J., Gardi, B., Ahmed, S. A., Sabir, B. Y., Ismael, N. B., Hamza, P. A., Sorguli, S., Ali, B. J., \& Anwar, G. (2021). Employee Commitment: The Relationship between Employee Commitment and Job Satisfaction. Journal of Humanities and Education Development, 3(3), 54-66.

Bao, Y., Dolan, S. L., \& Tzafrir, S. S. (2012). Value congruence in organizations: Literature review, theoretical perspectives, and future directions. ESADE Business School Research Paper.

Baron, R. M. \& Kenny, D. A. (1986). The Moderator-Mediator Variable Distinction in Social Psychological Research: Conceptual, Strategic, and Statistical Considerations. Journal of Personality and Social Psychology, 51, 1173-1182.

Bataineh, K. A. (2019). Impact of Work-Life Balance, Happiness at Work, on Employee Performance. International Business Research, 12(2), 99-112.

Bateman, T., \& Strasser, S. (1983). A cross-lagged regression test of the relationship between job tension and employee satisfaction. Journal of Applied Psychology, 68, 439-445.

Becker, C., Dustin \& Ostrom, E. (1995). "Human Ecology and Resource Sustainability: The Importance of Institutional Diversity." Annual Review of Ecology and Systematics, 26, 113-33.

23 Published by Research \& Innovation Initiative Inc., registered with the Michigan Department of Licensing \& Regulatory Affairs, United States (Reg. No. 802790777). 
Bhargava, S., \& Pradhan, H. (2017). Work Value Congruence and Job Performance: Buffering Role of Leader-Member Exchange and Core Self Evaluation. Asian Social Science, 13(1), 98-105.

Bissett, M. F. (2014). The role of values and value congruence for job satisfaction, person-organisation fit, work engagement, and resilience. A dissertation submitted in partial fulfillment of the requirements for the Degree of Master of Science in Applied Psychology at the University of Canterbury Christchurch, New Zealand.

Cable, D. M., \& DeRue, D. S. (2002). The convergent and discriminant validity of subjective fit perceptions. Journal of Applied Psychology, 87, 875-884.

Chatman, J. A. (1991). Matching people and organizations: Selection and socialization in public accounting firms. In Academy of Management Proceedings, (1), 199-203.

Dunaetz, D. R., Smyly, C., Fairley, C. M., \& Heykoop, C. (2020). Values Congruence and Organizational Commitment in Churches: When Do Shared Values Matter? Psychology of Religion and Spirituality, 0(0), 1-5

Eisenberger, R., Huntington, R., Hutchison, S \& Sowa, D. (1986). Perceived Organization Support, Journal of Applied Psychology, 71, 500-507.

Erdogan, B., Bauer, T. N., Truxillo, D. M. \& Mansfield, L. R. (2012), "Whistle while you work a review of the life satisfaction literature", Journal of Management, 38 (4), 1038-1083.

Ferssizidis, P., Adams, L. A., Kashdan, T. B., Plummer, C., Mishra, A. \& Ciarrochi, J. (2010). Motivation for commitment to social values: The role of age and gender. Motivational Emotion, 34, 354-362.

Field, L. K., \& Buitendach, J. H. (2011). Happiness, work engagement, and organizational commitment of support staff at a tertiary education institution in South Africa. SA Journal of Industrial Psychology, 37 (1), 1-10.

Fisher, C. (2010). Happiness at Work. International Journal of Management Reviews, 12, 384-412.

Gangai, K. N., \& Agrawal, R. (2015). Job Satisfaction and Organizational Commitment: Is It important for Employee Performance. Nt. J. Manag. Bus. Res., 5(4), 269-278.

Gavin, J. H. \& Mason, R. O. (2004), "The virtuous organization: the value of happiness in the workplace", Organizational Dynamics, 33(4), 379-92.

Garson, D. (2016). Partial Least Squares: Regression \& Structural Equation Models. USA: Statistical Associates Publishing.

Gulbahar, A. A., Kundi, G. M., Qureshi, Q. A., \& Akhtar, R. (2014). Relationship between Work-Life Balance \& Organizational Commitment. Research on Humanities and Social Sciences, 4(5), 1-7.

Gündüz, Y. (2014). The Effect of Organizational Support on Organizational Commitment The Effect of Organizational Support on Organizational Commitment. Anthropologist, $18(3), \quad 1051$. https://doi.org/10.1080/09720073.2014.11891587.

Hansen, J. P. \& Kjeldsen, A. M. (2017): Comparing Affective Commitment in the Public and Private Sectors: A Comprehensive Test of Multiple Mediation Effects. International Public Management Journal, 1-65.

Hair, J., Black, W., Babin, B., \& Anderson, R. (2014). Multivariate data analysis (7th ed.). UK: Pearson New International Edition.

Hoffman, B. J., Bynum, B. H., Piccolo, R. F., \& Sutton, A. W. (2011). P-O value congruence: How transformational leaders influence workgroup effectiveness. Academy of Management Journal, 54(4), 779-796.

Isreal, G. D. (2013). Determining sample size. Journal of Business Research, 1(1), 1-5.

Johnson, D. S. (2020). Public Versus Private Employees: A Perspective on the Characteristics and Implications. Perspective, 9(1), 9-14. https://doi.org/10.1177/2319714519901081

Joo, B. \& Lee, I. (2017) "Workplace happiness: work engagement, career satisfaction, and subjective well-being", Evidencebased HRM: A Global Forum for Empirical Scholarship, 5(2), 206-221.

Leuty, M. E., \& Hansen, J. I. (2012). Building evidence of validity: The relation between work values, interests, personality, and personal values. Journal of Career Assessment, 21(2), 175-189.

Liedtka, J. M. (1989). Value congruence: The interplay of individual and organizational value systems. Journal of Business Ethics, 8(10), 805-815.

Lyubomirsky, S. \& Lepper, H.S. (1999), "A measure of subjective happiness: preliminary reliability and construct validation", Social Indicators Research, 46(2), 137-155.

Mateu, D. Á. (2015). Happiness At Work, Business Administration And Marketing Department Ae1049 - Final Degree Project, Universitat Jaume.

Maurer, T. J., Lippstreu, M. \& Judge, T. A. (2008). Structural model of employee involvement in skill development activity: The role of individual differences. Journal of Vocational Behavior. 72, 336-350.

Meyer, J. P., Stanley, D. J., Herscovitch, L., \& Topolnytsky, L. (2002). Affective, continuance, and normative commitment to the organization: A meta-analysis of antecedents, correlates, and consequences. Journal of Vocational Behavior, 61, 20-52.

24 Published by Research \& Innovation Initiative Inc., registered with the Michigan Department of Licensing \& Regulatory Affairs, United States (Reg. No. 802790777). 
Mohammed, S. S., Suleyman, C., \& Taylan, B. (2020). Burnout Determinants and Consequences among University Lecturers. Amazonia Investiga, 9(27), 13-24.

Mooday, R.T., Porter, L.W., \& Steer, R.M. (1982). Employees' organization linkages. New York: Academic Press.

Moreno, F. Z., \& Ibarra, M. L. E. (2017). Practical application of the Lima Happiness Scale in workers of service companies at Barquisimeto, Venezuela. Cuadernos de Administración, 33(59), 64-78.

Northcraft, T. \& Neale, H. (1996). Organisation Behaviour. London: Prentice-Hall

Ndubuisi-Okolo, P. U., Emmanuel, A. Y., \& Anigbogu, T. (2017). Influencing Employees Job Attitude In Nigeria : A Critical Review. IOSR Journal of Business and Management, 19(12), 35-40. http://doi.org/10.9790/487X-1912023540

Ogunrotifa, A. B. (2014). Federal civil service reform in Nigeria: The case of democratic centralism. Radix International Journal of Research in Social Science, 1(10), 1-45.

Oyo-Ita, W. (2018, January 2). Vanguard Newspaper https://www.vanguardngr.com/2018/01/oyo-ita-tasks-federal-civilservants-higher-productivity-2018/amp/

Porters, L. W., Steers, R. M., Mowday, R. T. \& Boulin, P. V. (1974). Organizational Commitment, Job Satisfaction, and Turnover among Psychiatric Technicians. Journal of Applied Psychology, 59, 603-609.

Radosavljević, Ž., Vesna, Ć., \& Dragić, M. (2017). Employee Organizational Commitment. International Review, 2(1), 18-26.

Rao, R. (2010). What is Workplace Spirituality? Research in Organizational Behavior, 3, 1-52.

Richwine, J. (2012). Government Employees Work Less than Private-Sector Employees. The heritage foundation: Greenwich, CT: JAI Press.

Ryan, R. M. \& Deci, E. L. (2001). On happiness and human potentials: a review of research on hedonic and eudemonic wellbeing. Annual Review of Psychology, 52, 141-166.

Salisu, M. (2001). Incentive structure, civil service efficiency, and the hidden economy in Nigeria, WIDER Discussion Paper, No. 2001/86, The United Nations University World Institute for Development Economics Research (UNU-WIDER), Helsinki

Sortheix, F. M. (2014). Values and Well-Being in Context : An analysis of country and group influences. Department of Social Research, University of Helsinki.

Susniene, D., \& Jurkauskas, A. (2009). The Concepts of Quality of Life and happiness -Correlation and Differences. Inzinerine Ekonomika-Engineering Economics, 3, 58-65.

Tabane, T., Bosch, A., \& Roodt, G. (2019). Organisation value-person value congruence and the relation to organisational commitment Organisation value-person value congruence and the relation to organisational commitment. South African Journal of Labour Relations, 37(1), 39-60

Veage, S., Ciarrochi, J., Deane, F. P., Andresen, R., Oades, L. G., \& Crowe, T. P. (2014). Value congruence, importance and success and in the workplace: Links with well-being and burnout amongst mental health practitioners. Journal of Contextual Behavioral Science, 3, 258-264.

Wesarat, P., Sharif, M. Y., Halim, A., \& Majid, A. (2017). A Conceptual Framework of Happiness at the Workplace, 11(2), 78-88.

Yamane, T. (1967). Statistics: An Introductory Analysis, 2nd Ed., New York: Harper and Row.

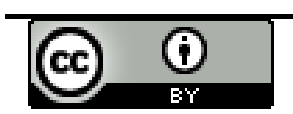

(C) 2021 by the authors. Licensee Research \& Innovation Initiative Inc., Michigan, USA. This article is an open-access article distributed under the terms and conditions of the Creative Commons Attribution (CC BY) license (http://creativecommons.org/licenses/by/4.0/).

25 Published by Research \& Innovation Initiative Inc., registered with the Michigan Department of Licensing \& Regulatory Affairs, United States (Reg. No. 802790777). 


\section{Appendix \\ Questionnaire}

Listed below are questions on Organizational Commitment, Work Happiness, and Value Congruence. Using the five-point scale provided, please indicate your level of agreement or disagreement with each statement.

\begin{tabular}{|c|c|c|c|c|c|c|}
\hline & Organizational Commitment & SA & $\mathbf{A}$ & $\mathbf{U}$ & $\mathbf{D}$ & SD \\
\hline 1 & I would be very happy to spend the rest of my career with this organization. & & & & & \\
\hline 2 & I really feel as if this organization's problems are my own & & & & & \\
\hline 3 & This organization has a great deal of personal meaning for me. & & & & & \\
\hline 4 & I do not feel a strong sense of belonging to my organization. & & & & & \\
\hline 5 & I do not feel 'emotionally attached' to this organization. & & & & & \\
\hline \multirow[t]{2}{*}{6} & I do not feel like 'part of the family' at my organization. & & & & & \\
\hline & Work Happiness & & & & & \\
\hline 7 & In general, I consider myself a very happy person & & & & & \\
\hline 8 & Compared to most of my peers, I consider myself happier & & & & & \\
\hline 9 & My coworkers are generally very happy. & & & & & \\
\hline \multirow[t]{2}{*}{10} & In our place of work, we enjoy life regardless of what is going on & & & & & \\
\hline & Value Congruence & & & & & \\
\hline 11 & $\begin{array}{l}\text { The thing that I value in life is very similar to the thing that my organization } \\
\text { values }\end{array}$ & & & & & \\
\hline 12 & My personal value match my organization values and culture & & & & & \\
\hline 13 & My organization values and culture provide a good fit with the thing I value in life & & & & & \\
\hline
\end{tabular}

